\title{
Antibacterial Properties and Corrosion Resistance of the Newly Developed Biomaterial, Ti-12Nb-1Ag Alloy
}

\author{
Je-Kang Du ${ }^{1,2}$, Chih-Yeh Chao ${ }^{3}$, Kuan-Yu Chiu ${ }^{1}$, Yen-Hao Chang ${ }^{1}$, Ker-Kong Chen ${ }^{1,2, *}$, \\ Ju-Hui $\mathrm{Wu}^{2,4, *}$ and Juyn-Nan $\mathrm{Wu}^{3}$
}

1 School of Dentistry, College of Dental Medicine, Kaohsiung Medical University, No. 100, Shih-Chuan 1st Road, Kaohsiung 80708, Taiwan; dujekang@gmail.com (J.-K.D.); godckw@gmail.com (K.-Y.C.); yhchang830@gmail.com (Y.-H.C.)

2 Department of Dentistry, Kaohsiung Medical University Hospital, Kaohsiung 80708, Taiwan

3 Department of Mechanical Engineering, National Pingtung University of Science and Technology, Pingtung 91201, Taiwan; cychao@mail.npust.edu.tw (C.-Y.C.); wu098787@gmail.com (J.-N.W.)

4 Department of Oral Hygiene, College of Dental Medicine, Kaohsiung Medical University, No. 100, Shih-Chuan 1st Road, Kaohsiung 80708, Taiwan

* Correspondence: enamel@kmu.edu.tw (K.-K.C.); wujuhui1020@gmail.com (J.-H.W.); Tel.: +886-7-3121-101 (ext. 7002) (K.-K.C.); +886-7-3121-101 (ext. 7007) (J.-H.W.); Fax: +886-7-3157-024 (K.-K.C. \& J.-H.W.)

Received: 3 October 2017; Accepted: 11 December 2017; Published: 15 December 2017

\begin{abstract}
Currently, the development of biomaterials has focused on having a low Young's modulus, biocompatibility, corrosion resistance, and antibacterial properties. Ti-Nb alloys have higher research value due to their excellent corrosion resistance and low Young's modulus. In recent years, the antibacterial properties of materials have been enhanced by the addition of $\mathrm{Ag}$ and $\mathrm{Cu}$. Therefore, the corrosion resistance and antibacterial properties of the Ti- $12 \mathrm{Nb}-1 \mathrm{Ag}$ alloy formulated in the current study were investigated and compared to those of commonly used Ti alloys, G2 pure Ti (ASTM B348 CP Grade 2), and Ti-6Al-4V, via electrochemical and E. coli antibacterial tests. Meanwhile, we also carried out a microstructural analysis to investigate the composition of the alloy. The results were as follows: (1) The electrochemical test demonstrated that $\mathrm{Ti}-12 \mathrm{Nb}-1 \mathrm{Ag}$ had a higher corrosion resistance than Ti-6Al-4V, which is similar to the properties of pure Ti. (2) The E. coli antibacterial test demonstrated that the sterilization rate of $\mathrm{Ti}-12 \mathrm{Nb}-1 \mathrm{Ag}$ was higher than that of the Ti-6Al-4V alloy and pure Ti. (3) The microstructural analysis revealed that $\mathrm{Ti}-12 \mathrm{Nb}-1 \mathrm{Ag}$ had an acicular martensite structure, with nano-Ag precipitates observed. Based on the results of the E. coli antibacterial test and the principles of sterilization of nano-precipitates and Ag, we inferred that the nano-Ag precipitates of $\mathrm{Ti}-12 \mathrm{Nb}-1 \mathrm{Ag}$ enhanced the antibacterial properties of the newly developed biomaterial, which is, namely, the Ti-12Nb-1Ag alloy.
\end{abstract}

Keywords: $\mathrm{Ti}-12 \mathrm{Nb}-1 \mathrm{Ag}$ alloy; antibacterial properties; electrochemistry; nano-Ag precipitates; microstructural analysis

\section{Introduction}

Pure Ti and Ti alloys are two of the most popular biomaterials in use today due to their favorable properties, such as biocompatibility, mechanical properties, and corrosion resistance [1-3]. These alloys have a considerably wide range of biomedical applications, such as dental implants, crowns, and bridges; orthodontic wires; bone plates; hip joints; and spinal fixation devices $[4,5]$. These alloys also have higher corrosion resistance and biocompatibility compared with stainless steel (e.g., $316 \mathrm{~L}$ and 304), which is widely used in the field of biomaterials [6-8]. Furthermore, these alloys do not cause allergic reactions in the surrounding tissues or hemagglutination [9], while also having 
a relatively low density. For these reasons, Ti alloys have been gradually replacing stainless steel in the field of biomaterials.

According to American Society for Testing and Materials (ASTM) F67 standards, CP titanium is produced at four different degrees of purity (grades 1-4), based on the maximum content of interstitial impurities (higher content is assigned a higher grade). Such interstitial defects can prevent movement and dislocations within the lattice, therefore augmenting the mechanical strength and reducing ductility $[10,11]$. Pure titanium is frequently used in many applications, as it exhibits good weldability, ductility, and formability $[10,11]$. However, pure Ti has the problems of insufficient strength and poor wear resistance, both of which have limited its application. For example, the demand for strength of artificial joints is high and, therefore, some researchers have tried to use the solid solution technique to increase its strength $[4,10,11]$. Over the past 10 years, the low-density Ti alloy Ti-6Al-4V has become one of the most popular materials used in implants. However, studies have shown that Ti-6Al-4V has adverse effects on the human body because ions of $\mathrm{Al}$ and $\mathrm{V}$ can be released. The $\mathrm{V}$ ions can bind to inorganic phosphorus, leading to a phosphorus deficiency, while $\mathrm{Al}$ possesses neurotoxic properties. These effects can lead to several medical conditions, such as Alzheimer's Disease and reduced fertility $[1,9,12,13]$. Therefore, new Ti alloys need to be developed to replace the existing Ti-6Al-4V alloy.

As Ti alloys are widely applied in the biomedical field, they must have a Young's modulus similar to human bone so as to not cause serious stress shielding, which leads to implant loosening and revision surgery. If the Young's modulus is too high, it can lead to stress shielding effects. This is the case for Ti-6Al-4V as its Young's modulus is 108-110 GPa, which is threefold higher than that of human bone (human bone: 30-33 GPa). This, subsequently, will cause resorption of adjacent bone tissue and premature failure of prosthetic devices due to the large differences in the elastic moduli between the implant and the adjacent bone tissue [1,14-16]. Hence, the focus regarding the development of new $\mathrm{Ti}$ alloys is on materials that have a low Young's modulus.

In recent years, $\mathrm{Ti}$ alloys, such as $\mathrm{Ti}-\mathrm{Mo}$, $\mathrm{Ti}-\mathrm{Ta}$, and $\mathrm{Ti}-\mathrm{Nb}$, have been studied extensively due to their low modulus values and nontoxic properties $[17,18]$. It has been shown that the addition of $\mathrm{Mo}, \mathrm{Ta}$, and $\mathrm{Nb}$ to Ti can enhance the tensile strength of the alloyed material and reduce its Young's modulus [19-22]. In fact, the addition of different elements can enhance specific properties of the material. For example, the addition of Mo to Ti enhances its porosity, thus reducing its Young's modulus [23]; the addition of Ta to Ti forms a stable coating on the surface of the Ti from the high chemical activity of Ta imparting higher chemical stability and corrosion resistance to the Ti-Ta alloy [24,25]; and the addition of $\mathrm{Nb}$ to Ti improves shape memory, which is beneficial to its application in the biomedical field $[18,26]$.

However, recent studies into the development of Ti alloys have revealed some drawbacks. For example, the addition of Mo to Ti increases the density of the Ti alloy, which will adversely affect its mechanical properties. In contrast, Ta is expensive, which increases the material costs [24]. Therefore, in the current study, we selected Ti-Nb alloys as our research focus. In previous studies on $\mathrm{Ti}-\mathrm{Nb}$ alloys, the proportion of $\mathrm{Nb}$ ranged from $10-40 \%[1-3,12,18,27]$. Therefore, for our research, we chose an alloy composition of $12 \%$, which is referred to as $\mathrm{Ti}-(12 \%) \mathrm{Nb}$. We also used the alloy phase diagram to make this selection.

Dental implant materials should exhibit favorable antibacterial properties. Bacteria that adhere to medical equipment form a biofilm on the surface, which protects them from sterilization by antibacterial agents. Eventually, this can lead to complications, such as infection, in living tissues that come into contact with the medical equipment [28-30]. To solve this problem, many researchers have found that addition of $\mathrm{Ag}$ can reduce bacterial colonization, leading to improved antibacterial properties of the material. However, excessive antibacterial properties can actually damage cells and inhibit the self-repair capacity of the surrounding tissues [28,31]. The addition of $\mathrm{Cu}$ can also enhance the antibacterial properties of a material, which has been the trend in the development of antibacterial stainless steel in recent years [32,33]. The use of metals, such as $\mathrm{Cu}$ and $\mathrm{Ag}$, achieves an 
antibacterial effect by damaging the cell wall and cell membranes of the bacteria via the strong oxidizing characteristic of the metal ions, which eventually inhibits the metabolism of the bacteria [34]. Corrosion resistance has also been the focus of recent studies, as materials used in dental implants face the unique problem of contact with fluoride ions from dental treatment products. Fluorides can cause destruction of the inert layer, which substantially increases the corrosion rate of the implant [35]. In previous studies, researchers have used various materials and methods such as a mechanical-resistant bioactive layer, a plasma spray, a sol-gel, electrochemical deposition techniques, acid-etching, and anodic oxidation on the surface of the materials to improve their antibacterial properties, corrosion resistance, and biocompatibility $[25,36,37]$. However, these materials and methods were largely unsuccessful. Therefore, in the current study, we homogenized the materials using the melting method to ensure homogeneous and persistent dissolution of the metal ions in order to achieve enduring efficacy [38,39].

In summary, the alloy formulated in the present study was mainly composed of $\mathrm{Ti}$ and $\mathrm{Nb}$, with some Ag added to enhance its antibacterial properties. The silver had a lower toxicity to human cells compared with copper, with the addition of copper also making it difficult to maintain both corrosion resistance and good antibacterial properties [40]. The purpose of adding silver is to utilize its antibacterial properties [41-47] in order to enable sterilization of the alloy, thereby enhancing the antibacterial properties of the biomaterial. To ensure the solid solution of the alloy with Ag, we used the Ti-Ag binary phase diagram [48] and formulated the alloy composition of $\mathrm{Ti}-12 \mathrm{Nb}-1 \mathrm{Ag}$, before analyzing the antibacterial properties of $\mathrm{Ti}-12 \mathrm{Nb}-1 \mathrm{Ag}$. We also compared the corrosion resistance and antibacterial properties of $\mathrm{Ti}-12 \mathrm{Nb}-1 \mathrm{Ag}$ with commonly used $\mathrm{Ti}$ alloys, such as G2 pure Ti and Ti-6Al-4V. We compared the corrosion resistance of the materials using an electrochemical test and their antibacterial properties via an E. coli antibacterial test. We also further analyzed their microstructures in order to better understand the correlation between microstructural and antibacterial properties.

\section{Materials and Methods}

In this study, $\mathrm{Ti}-12 \mathrm{Nb}-1 \mathrm{Ag}$ was formulated in order to develop biomedical materials with appropriate properties. We conducted an antibacterial assay, electrochemical corrosion tests, and a microstructural analysis in order to investigate the correlation between structural and functional properties. The experimental procedure is shown in Figure 1.

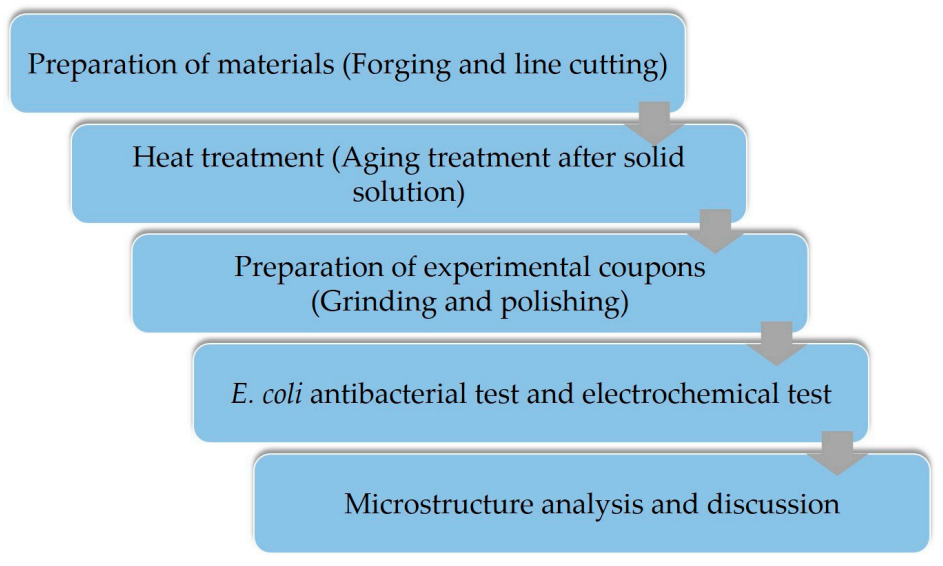

Figure 1. Flowchart of the experimental procedure.

\subsection{Preparation of Materials}

The alloy composition formulated in this study was $\mathrm{Ti}-12 \mathrm{Nb}-1 \mathrm{Ag}$, as shown in Table 1 . The alloy was purified in duplicate using a vacuum induction melting furnace in order to decrease gravity segregation in casting. After this, it was shaped by open die forging into $100.502 \mathrm{~mm}^{3}$ sized plates. Finally, the plates were cut into $2 \mathrm{~mm}$ thick slices, with dimensions of $10 \mathrm{~mm} \times 10 \mathrm{~mm}$ (length $\times$ width). 
Table 1. Chemical Composition of $\mathrm{Ti}-12 \mathrm{Nb}-1 \mathrm{Ag}$.

\begin{tabular}{cccccccccc}
\hline Element & $\mathbf{T i}$ & $\mathbf{N b}$ & $\mathbf{A g}$ & $\mathbf{O}$ & $\mathbf{C}$ & $\mathbf{S i}$ & $\mathbf{N}$ & $\mathbf{F e}$ & $\mathbf{C r}$ \\
\hline Mass $\%$ & Bal. & 12.12 & 1.05 & 0.12 & 0.04 & 0.12 & 0.03 & 0.12 & 0.08 \\
\hline
\end{tabular}

\subsection{Conditions for Heat Treatment}

The conditions for heat treatment were as follows: high temperature solid solution treatment at $850^{\circ} \mathrm{C}$ for $1 \mathrm{~h}$, followed by water-cooling, aging at $550^{\circ} \mathrm{C}$ for $8 \mathrm{~h}$, and further water-cooling.

\subsection{Preparation of Experimental Samples}

Experimental samples of Ti-12Nb-1Ag, G2 pure Ti, and Ti-6Al-4V were prepared using a cutting machine (SEIBU SNC-20HPi, Kyushu, Japan), which cut the samples into $2 \mathrm{~mm}$ thick, $10 \mathrm{~mm} \times 10 \mathrm{~mm}$ slices. After this, the Ti-12Nb-1Ag experimental samples were subjected to heat treatment using the predetermined conditions. After heat treatment, the samples were added to an epoxy hardener in a cold mounting press, followed by grinding sequentially with 100, 600, 1000, and 1500 grit waterproof abrasive paper (MATADOR, Remscheid, Germany). After that, the samples were subjected to polishing using alumina powder $\left(\mathrm{Al}_{2} \mathrm{O}_{3}\right)$ with $0.3 \mu \mathrm{m}$ particle size, which was followed by secondary polishing with silicon dioxide $\left(\mathrm{SiO}_{2}\right)$. Finally, the samples were subjected to a water polish to remove surface impurities.

\subsection{Analysis of Antibacterial Properties}

An antibacterial assay was used to assess the antibacterial properties of the material surface. The assay was carried out according to JIS Z2801:2000 specifications. After the experimental samples were sterilized by UV (UV-101, Winder, GA, USA), Escherichia coli (E. coli [ATCC-25922]) was inoculated onto the surface of the samples at a density of $10^{7} \mathrm{CFU}$ (cells $/ \mathrm{mL}$ ). After a $20 \mathrm{~h}$ incubation, a series of observations and assays were conducted at various time points.

\subsubsection{Antibacterial Assay of Experimental Samples}

Bacterial culture medium (BD Triptose Enzymatic Digest of protein) was added to the test tubes and sterilized via autoclaving for $10-15 \mathrm{~min}$, before it was cooled to room temperature (about $25^{\circ} \mathrm{C}$ ). The bacteria were inoculated into the cooled bacterial culture medium using a platinum loop, followed by incubation at $37^{\circ} \mathrm{C}$ for $12 \mathrm{~h}$. An appropriate volume of bacterial culture was transferred into a cuvette to measure the optical density (OD) value using an ultraviolet-visible spectroscopy (UV-vis) spectrophotometer (BioMate3, Grand Island, NY, USA) in order to obtain the bacterial cell density in $\mathrm{CFU}$ (cells $/ \mathrm{mL}$ ). The measured bacterial culture was diluted to a density of $10^{7} \mathrm{CFU}$ prior to inoculation of the samples, followed by a $20 \mathrm{~h}$ incubation in a shaking incubator to prevent the precipitation of bacterial cells. To determine bacterial growth, the OD value of the bacterial culture was measured using a UV-vis spectrophotometer. The antibacterial rate (AR) can be obtained by the following formula:

$$
\mathrm{AR}=\left(\mathrm{OD}_{\text {control }}-\mathrm{OD}_{\text {sample }}\right) / \mathrm{OD}_{\text {control }} \times 100 \% \text {, }
$$

where $\mathrm{OD}_{\text {control }}$ and $\mathrm{OD}_{\text {sample }}$ are the average $\mathrm{OD}$ values of the bacterial colonies of the control group and samples, respectively.

\subsubsection{Bacterial Count}

A UV-vis spectrophotometer was used to determine the actual number of viable bacterial cells on the samples. A 2\% bacterial culture medium (BD Triptose Enzymatic Digest of protein), supplemented with $2 \%$ agar was sterilized via autoclaving for $10-15 \mathrm{~min}$, before an appropriate volume of the molten agar was poured into a petri dish $(90 \mathrm{~mm} \times 15 \mathrm{~mm})$. The petri dish was then inverted, cooled in a ventilation chamber and sterilized using UV radiation. The bacterial culture was diluted to a density of 10-100 CFU, transferred onto the agar plate and spread using an L-shaped cell spreader until dry. 
The agar plate was then incubated at $37^{\circ} \mathrm{C}$ for $12 \mathrm{~h}$ prior to counting of the number of colonies, which aimed to determine the actual number of viable bacterial cells. The above-mentioned procedure was repeated five times to obtain a mean value for comparison.

\subsection{Electrochemical Analysis}

The samples to be tested were polished by sandpaper of a grade higher than 1200 grit. A $10 \mathrm{~mm} \times 10 \mathrm{~mm}$ area was marked on the top surface of the samples while the bottom was connected to the solid conductors. Following this, the entire surface of the samples and the constantan wire were coated with multi-part adhesives (Magnobond\#6375, Chamblee, GA, USA) or a nonconductive coating, leaving only the $10 \mathrm{~mm} \times 10 \mathrm{~mm}$ area exposed. The conductivity between the constantan wire and the samples was tested.

To investigate corrosion resistance of the samples, a $600 \mathrm{E}$ electrochemical station was used ( $\mathrm{CH}$ Instruments, Inc., Austin, TX, USA). For the measurements, the reference electrode (ANATECH Co., Ltd., Taipei, Taiwan), counter electrode, and working electrode were a saturated calomel electrode, a platinum sheet, and test samples, respectively. The three electrodes were sequentially placed into the reagent bottle and their positions were adjusted. To simulate the environment in mouths, artificial saliva $\left(0.4 \mathrm{~g} \mathrm{KCl}, 0.4 \mathrm{~g} \mathrm{NaCl}, 0.906 \mathrm{~g} \mathrm{CaCl}_{2} \cdot 2 \mathrm{H}_{2} \mathrm{O}, 0.690 \mathrm{~g} \mathrm{NaH}_{2} \mathrm{PO}_{4} \cdot 2 \mathrm{H}_{2} \mathrm{O}, 0.005 \mathrm{~g} \mathrm{Na} 2 \mathrm{~S} \cdot 9 \mathrm{H}_{2} \mathrm{O}\right.$, and $1 \mathrm{~g}$ urea per liter) was used as a corrosive fluid, before aerated nitrogen was allowed to deaerate for $30 \mathrm{~min}$. Prior to the potential polarization testing, the open circuit potential (OCP) of the samples was measured and recorded to determine the scan range at a scan rate of $1 \mathrm{mv} / \mathrm{s}$. The experimental data were plotted as a logarithmic voltage-current density curve to obtain values for the corrosion potential $\left(E_{\text {corr }}\right)$ and the corrosion current density $\left(I_{\text {corr }}\right)$. According to ISO 10271:2001 specifications, the recorded curve of offload voltage versus time should be $1 \mathrm{~h}$ long to confirm the off-load voltage $\left(E_{\mathrm{OCP}}\right)$. Electric potential scanning was performed at a scanning rate of $0.5 \mathrm{mV} \mathrm{s}^{-1}$.

\subsection{Analysis of Microstructure}

A microstructural analysis was performed via SEM (scanning electron microscopy) (JEOL JSM-6380, Tokyo, Japan) and TEM (transmission electron microscopy) (Philips CM200 FEG, Tempe, AZ, USA). The experimental procedures were as follows.

For SEM, a corrosive fluid $\left(7.5 \% \mathrm{HNO}_{3}+2.5 \% \mathrm{HCl}+90 \%\right.$ alcohol $)$ was prepared to corrode the samples after polishing of the samples. SEM, using an operating voltage of $15 \mathrm{kV}$ and a vacuum maintaining $10^{-4} \mathrm{~Pa}$, was employed to observe the surface structural properties of the samples.

For TEM, the samples were polished via water sandpaper to $80 \mu \mathrm{m}$, before being electropolished using an Automatic Twin-Jet Electropolisher (Model 110, Kanagawa, Japan) at a working voltage of $30-40 \mathrm{~V}$ and a temperature of approximately -20 to $-10{ }^{\circ} \mathrm{C}$, with $85 \% \mathrm{CH}_{3} \mathrm{OH}+15 \% \mathrm{HClO}_{4}$ used as the corrosive fluid. TEM was used to observe the bright field, dark field, and selected area diffraction pattern (SADP) of the polished area of the samples in order to analyze the surface microstructure.

\section{Results}

\subsection{E. coli Antibacterial Testing of Ti-12Nb-1Ag}

The results of the E. coli antibacterial test are shown in Figure 2. The numbers of bacteria of the G2 pure Ti and Ti-6Al-4V were $3.33 \times 10^{6}$ and $3.29 \times 10^{6}$, which were similar to the control group $\left(3.50 \times 10^{6}\right)$. This indicated that their antibacterial properties were insignificant. However, the number of viable bacterial cells on $\mathrm{Ti}-12 \mathrm{Nb}-1 \mathrm{Ag}\left(1.06 \times 10^{6}\right)$ was much lower than that of the control group, indicating that it had favorable antibacterial ability. The antibacterial rates of pure Ti and Ti- $6 \mathrm{Al}-4 \mathrm{~V}$ were $4.9 \%$ and $6 \%$, respectively. However, the Ti- $12 \mathrm{Nb}-1 \mathrm{Ag}$ alloy exhibited stronger antibacterial properties, which were as high as $71.4 \%$. 


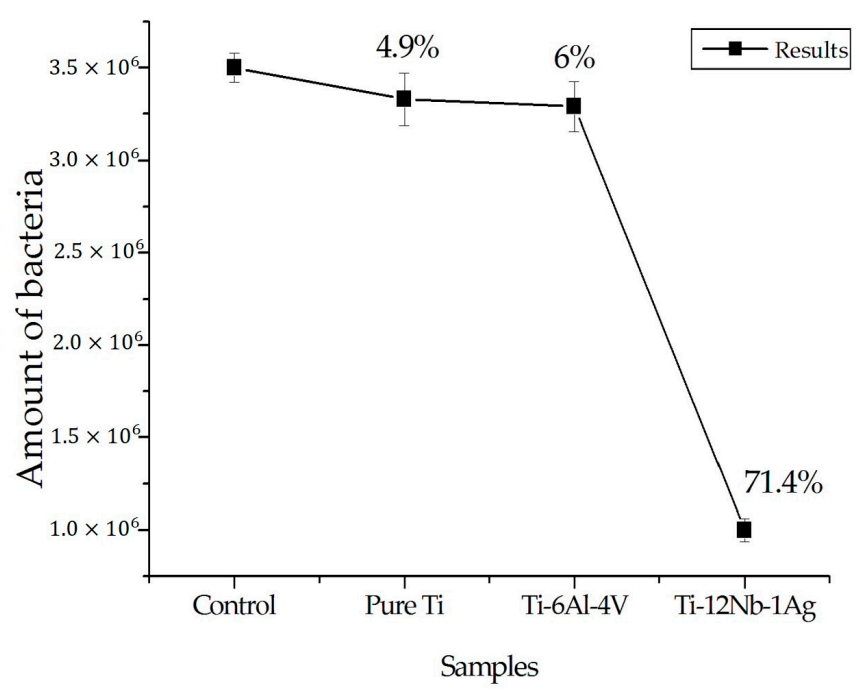

Figure 2. Comparison of $E$. coli antibacterial test results of pure Ti with $\mathrm{Ti}-6 \mathrm{Al}-4 \mathrm{~V}$ and $\mathrm{Ti}-12 \mathrm{Nb}-1 \mathrm{Ag}$ alloys.

\subsection{Electrochemical Testing of $\mathrm{Ti}-12 \mathrm{Nb}-1 \mathrm{Ag}$}

Figure 3a shows the potentiodynamic polarization curves of the Ti-12Nb-1Ag alloy, Ti-6Al-4V, and pure $\mathrm{Ti}$ in the artificial saliva. The three Ti alloys all possess similar passive properties with low currents, which indicate a low corrosion ratio. Meanwhile, no significant breakdown potential is observed, which indicates that the phenomenon of pitting corrosion does not occur during the electrochemical measurement. However, the corrosion potential of the $\mathrm{Ti}-12 \mathrm{Nb}-1 \mathrm{Ag}$ alloy $\left(E_{\text {corr }}=-0.264 \mathrm{eV}\right)$ was slightly lower than that of pure $\mathrm{Ti}\left(E_{\text {corr }}=-0.244 \mathrm{eV}\right)$ and better than that of Ti-6Al- $4 \mathrm{~V}\left(E_{\text {corr }}=-0.461 \mathrm{eV}\right)$. Based on the estimation of the corrosion potential, the corrosion tendency of the Ti-12Nb-1Ag alloy was lower than that of the Ti-6Al-4V, which was similar to that of the pure Ti. However, as shown in Figure $3 b$, the Ti-12Nb-1Ag alloy curve is located at the top, with the pure Ti curve just below it and the Ti-6Al-4V curve at the bottom. These curves indicate that the potential curve had reached a steady state in the long-term electrochemical test. The passivation layer, which provides better corrosion resistance, could become thicker with a higher OCP. Thus, the comprehensive electrochemical characteristic of the Ti-12Nb-1Ag alloy was higher than that of $\mathrm{Ti}-6 \mathrm{Al}-4 \mathrm{~V}$ and even outperformed the pure Ti.
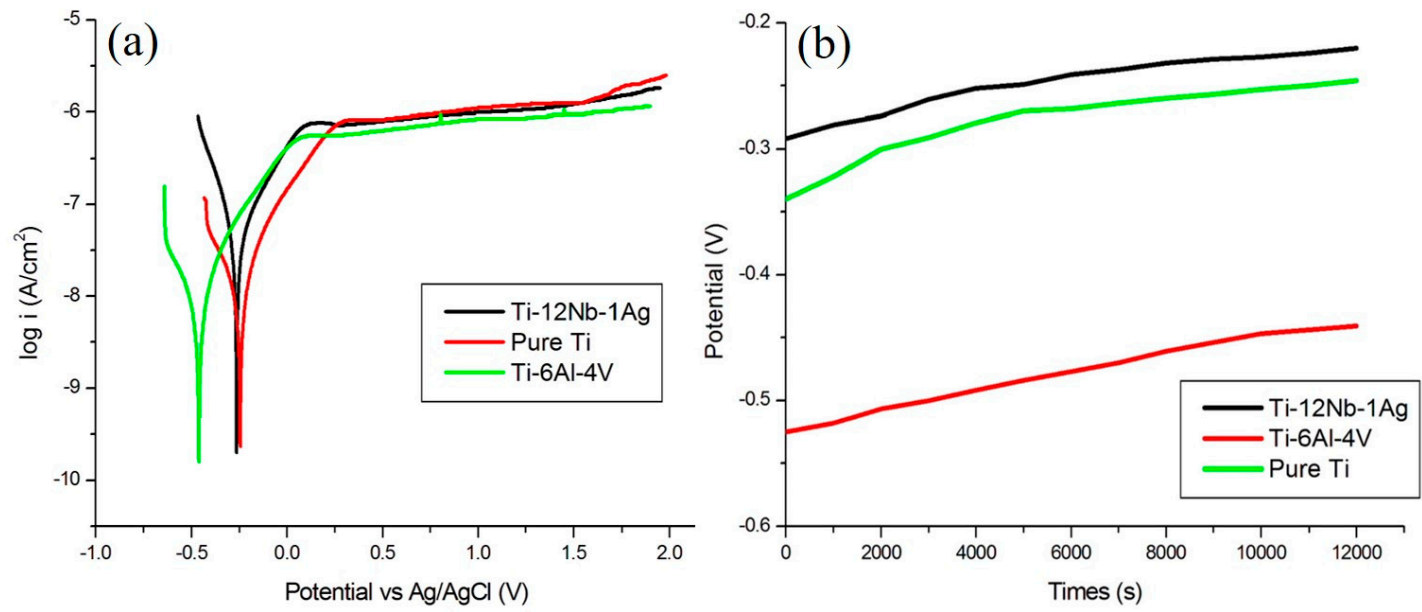

Figure 3. Electrochemical test results of Ti-12Nb-1Ag, G2 pure Ti, and Ti-6Al-4V using: (a) Tafel curves and (b) Open-circuit potential curves. 


\subsection{Microstructural Analysis of the Ti-12Nb-1Ag Alloy}

To describe in detail the properties of the different alloys, microstructural analysis was also performed. The TEM observation of $\mathrm{Ti}-12 \mathrm{Nb}-1 \mathrm{Ag}$ after solid solution treatment and aging treatment is described below.

At low magnification, it could be seen that $\mathrm{Ti}-12 \mathrm{Nb}-1 \mathrm{Ag}$ had an acicular structure. The bright field image is shown in Figure $4 \mathrm{a}$, while the dark field image is shown in Figure $4 \mathrm{~b}$. Figure 4c indicates that the base was $\alpha$-Ti, the hexagonal close packing (hcp) structure and lattice constants were $\mathrm{a}=0.2952 \mathrm{~nm}$ and $c=0.4688 \mathrm{~nm}$, respectively, along the [110] axis.
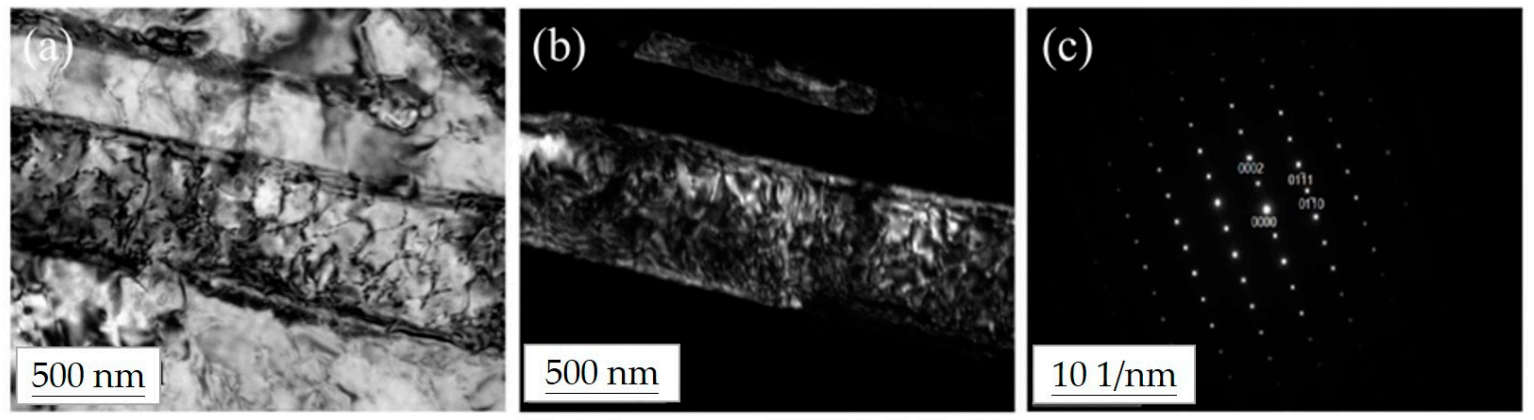

Figure 4. TEM (transmission electron microscopy) images for $\mathrm{Ti}-12 \mathrm{Nb}-1 \mathrm{Ag}$, including: (a) Bright field image, (b) Dark field image, and (c) [110] axis. These indicate that the material has an acicular hexagonal close packing (HCP) structure.

Figure 5a is a low-magnification bright field image after low-temperature aging, showing that more precipitates were observed. Figure $5 b$ is a high-magnification dark-field image, showing that approximately 50-100 nm nano-precipitates were observed. The smaller image shows the SADP of the $\alpha$-Ti base and additional weaknesses (precipitates). In addition to the diffraction point of the $\alpha$-Ti base, the diffraction point of the precipitates was also observed.

In summary, the microstructural observations of the $\mathrm{Ti}-12 \mathrm{Nb}-1 \mathrm{Ag}$ alloy revealed that the basic structure of the alloy was an HCP acicular martensite structure. Nano-precipitates were also observed on the coupons after low-temperature aging.
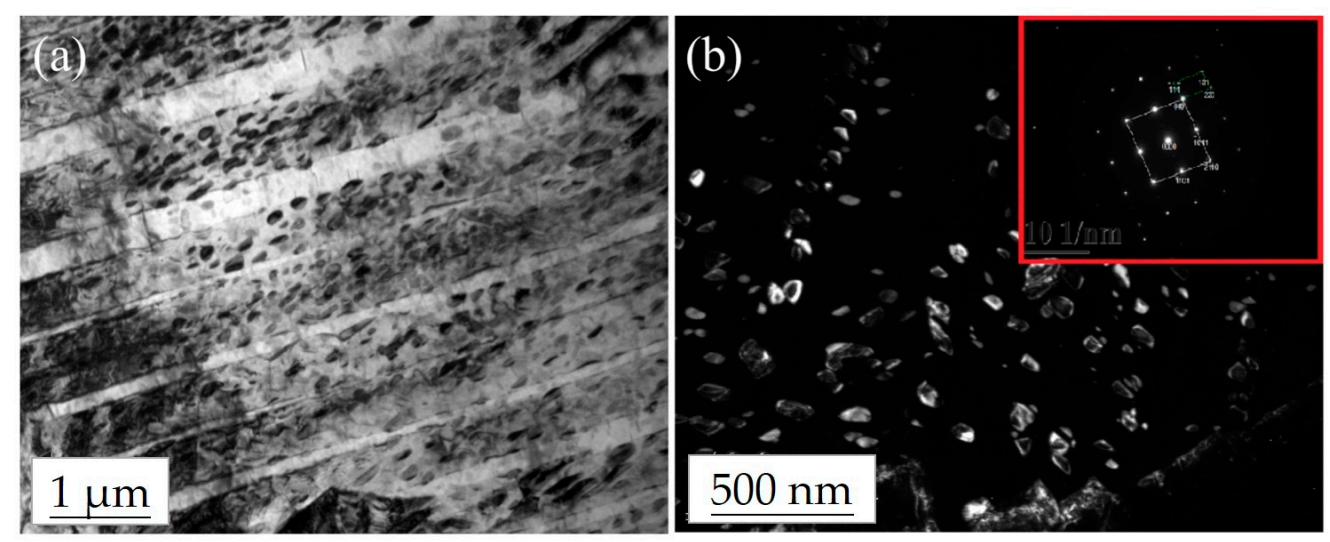

Figure 5. TEM (transmission electron microscopy) images, including: (a) Bright field image and (b) Dark field image. The smaller image is the [011] axis of the selected area diffraction pattern (SADP), which shows the presence of nano-sized particle precipitates after precipitation hardening of the material. 


\section{Discussion}

Dental implant materials should exhibit favorable antibacterial properties and corrosion resistance. Otherwise, an implant could cause various complications in the human body due to bacterial infection and metal ion release [49]. Ti-Nb alloys have been widely used in the medical field because of their excellent corrosion resistance and biocompatibility (being nontoxic and not rejected by the human body). In the current study, we aimed to enhance the antibacterial properties of $\mathrm{Ti}-\mathrm{Nb}$ alloys via the addition of silver $[50,51]$ in order to produce an alloy with good corrosion resistance and antibacterial properties. We compared the mechanical properties of Ti-12Nb-1Ag with G2 pure Ti and Ti-6Al-4V and correlated these results with those of microstructural analysis.

An E. coli antibacterial test was used to determine the antibacterial properties of the alloys relative to a control group. A lower number of viable bacterial cells indicated a better sterilization rate of the alloy. The test results showed that the Ti-12Nb-1Ag alloy had the lowest number of viable bacterial cells, with a sterilization rate higher than those of pure Ti and Ti-6Al-4V. Studies from other researchers also showed that pure $\mathrm{Ti}$ and $\mathrm{Ti}-6 \mathrm{Al}-4 \mathrm{~V}$ did not have significant antibacterial properties, which is consistent with the results from our present study $[39,49]$.

Electrochemistry is frequently used to analyze corrosion resistance [35,52,53], where it determines that a material with better electrochemical properties and a higher electrical potential will not be easily oxidized. Thus, such a material will not corrode easily after being implanted into the human body, which enhances the feasibility of in vivo application of the material [54]. The results of the current research showed that the corrosion electrical potential of the $\mathrm{Ti}-12 \mathrm{Nb}-1 \mathrm{Ag}$ alloy indicated excellent corrosion resistance, which was similar to that of pure Ti and higher than that of Ti-6Al-4V.

The results of the antibacterial test and the electrochemical test for the $\mathrm{Ti}-12 \mathrm{Nb}-1 \mathrm{Ag}$ alloy in this study were better than those for the G2 pure Ti and Ti-6Al-4V. Furthermore, the microstructural analysis revealed that the basic structure of the Ti-12Nb-1Ag alloy was that of an $\alpha$-Ti base and acicular martensite. Additionally, studies by other researchers found that the structure of martensite could be enhanced by altering the composition of $\mathrm{Nb}$. When the concentration of $\mathrm{Nb}$ in the Ti-Nb alloy was lower than $25.5 \%$, the alloy was an $\alpha$-phase structure [18], which is consistent with the results of the present study. However, additional weaknesses, such as some precipitates, were found in the SADP of the $\mathrm{Ti}-12 \mathrm{Nb}-1 \mathrm{Ag}$ alloy in addition to the diffraction spot of the $\alpha$-Ti base. From the lattice constant calculation, we inferred that it was the diffraction spot of Ag, namely $\mathrm{g}=$ [112] with fcc structure, when the lattice constant is $\mathrm{a}=0.369 \mathrm{~nm}$.

Studies by other researchers showed that Ag nanoparticles have excellent antibacterial effects in clinical and medical applications. Moreover, a comparison of Ag particles found that the antibacterial effects were enhanced by decreasing the size of the Ag particles [46,55]. Ou [56] reported that the strong antibacterial agents of $\mathrm{Ag}$ nanoparticles or $\mathrm{Ag}^{+}$ions could be released from $\mathrm{Ag}$-rich compounds precipitated in the matrix of the Ag-bearing $\mathrm{Ti}-27.5 \mathrm{Nb}$ alloys into the surrounding solution. Therefore, $\mathrm{Ag}$ nanoparticles or $\mathrm{Ag}^{+}$ions can destroy the cell walls or cell membranes of bacteria in order to inhibit their growth [57]. Thus, the Ag nanostructure might express favorable antibacterial effects. Furthermore, other studies also found that the shape of Ag particles could be altered via different materials and methods, including polyol processing, seed-mediated growth, electrochemical deposition, soft templates, and photochemical synthesis [58]. The fact that the shape of the Ag-rich precipitates correlates with their antibacterial properties was also reported in a previous study [59], which indicated that spherical and triangular Ag nanostructures have higher antibacterial properties than those of cubic and linear Ag-rich precipitates. However, although a triangular silver particle has a higher antibacterial property, it also has a higher silver release concentration than other shapes [60], which could lead to adverse effects in the human body. Therefore, we inferred that the spherical shape is the optimal nanostructure.

In summary, we infer that the alloys used in this study could possess good antibacterial properties because they contain nanoscale silver precipitates. The effect of the shape of the Ag nanostructure with 
polygonal or spherical shapes, which could exhibit favorable antibacterial properties and have fewer adverse effects on the human body, should be further analyzed.

\section{Conclusions}

In this study, the $\mathrm{Ti}-12 \mathrm{Nb}-1 \mathrm{Ag}$ alloy was the main focus and its structural properties possessing favorable biocharacteristics were investigated. Ag nanostructure (approximately 50-100 nm with a polygonal, near-spherical shape) was observed in the Ti-12Nb-1Ag alloy, which enhanced the antibacterial properties of the Ti-12Nb-1Ag alloy. The Ti-12Nb-1Ag alloy had outstanding corrosion resistance, which was similar to that of pure Ti. After having reached its steady state in the long term, the electrical potential of the Ti-12Nb-1Ag alloy was even higher than that of pure Ti, indicating that it would not be easily corroded in the human body.

E. coli antibacterial testing of the Ti- $12 \mathrm{Nb}-1 \mathrm{Ag}$ alloy compared with that of $\mathrm{G} 2$ pure Ti and Ti-6Al-4V alloys showed that both $\mathrm{G} 2$ pure $\mathrm{Ti}$ and the Ti-6Al-4V alloy did not have significant antibacterial properties, while the Ti-12Nb-1Ag alloy possessed better antibacterial properties (about $71 \%$ ).

In this study, we used a Ti-Nb alloy with silver added and confirmed that the resulting $\mathrm{Ti}-\mathrm{Nb}$ alloy displayed good corrosion resistance and good antibacterial properties.

Acknowledgments: This study was financially supported by the Ministry of Science and Technology grant MOST104-2314-B-037-057-MY2, MOST106-2314-B-037-013- and Kaohsiung Medical University Hospital grant KMUH104-4M48, KMUH105-5R63.

Author Contributions: Je-Kang Du and Ker-Kong Chen conceived and designed the experiments; Chih-Yeh Chao, Juyn-Nan $\mathrm{Wu}$ and Ju-Hui Wu performed the experiments; Je-Kang Du and Ju-Hui Wu analyzed the data; Je-Kang Du and Ju-Hui Wu contributed reagents/materials/analysis tools; Je-Kang Du, Kuan-Yu Chiu and Yen-Hao Chang wrote the paper.

Conflicts of Interest: The authors declare no conflicts of interest.

\section{References}

1. Hsu, H.-C.; Wu, S.-C.; Hsu, S.-K.; Syu, J.-Y.; Ho, W.-F. The structure and mechanical properties of as-cast $\mathrm{Ti}-25 \mathrm{Nb}-x \mathrm{Sn}$ alloys for biomedical applications. Mater. Sci. Eng. A 2013, 568, 1-7. [CrossRef]

2. Lopes, E.S.N.; Cremasco, A.; Afonso, C.R.M.; Caram, R. Effects of double aging heat treatment on the microstructure, vickers hardness and elastic modulus of Ti-Nb alloys. Mater. Charact. 2011, 62, 673-680. [CrossRef]

3. Mantani, Y.; Tajima, M. Phase transformation of quenched $\alpha^{\prime \prime}$ martensite by aging in Ti-Nb alloys. Mater. Sci. Eng. A 2006, 438-440, 315-319. [CrossRef]

4. Liu, H.; Niinomi, M.; Nakai, M.; Hieda, J.; Cho, K. Deformation-induced changeable Young's modulus with high strength in $\beta$-type Ti-Cr-O alloys for spinal fixture. J. Mech. Behav. Biomed. Mater. 2014, 30, $205-213$. [CrossRef] [PubMed]

5. Bai, Y.J.; Wang, Y.B.; Cheng, Y.; Deng, F.; Zheng, Y.F.; Wei, S.C. Comparative study on the corrosion behavior of $\mathrm{Ti}-\mathrm{Nb}$ and TMA alloys for dental application in various artificial solutions. Mater. Sci. Eng. C 2011, 31, 702-711. [CrossRef]

6. Latifi, A.; Imani, M.; Khorasani, M.T.; Joupari, M.D. Electrochemical and chemical methods for improving surface characteristics of 316L stainless steel for biomedical applications. Surf. Coat. Technol. 2013, 221, 1-12. [CrossRef]

7. Wang, L.; Zhao, X.; Ding, M.H.; Zheng, H.; Zhang, H.S.; Zhang, B.; Li, X.Q.; Wu, G.Y. Surface modification of biomedical AISI 316L stainless steel with zirconium carbonitride coatings. Appl. Surf. Sci. 2015, 340, 113-119. [CrossRef]

8. Zalnezhad, E.; Hamouda, A.M.S.; Faraji, G.; Shamshirband, S. $\mathrm{TiO}_{2}$ nanotube coating on stainless steel 304 for biomedical applications. Ceram. Int. 2015, 41, 2785-2793. [CrossRef]

9. Huang, H.-H.; Wu, C.-P.; Sun, Y.-S.; Lee, T.-H. Improvements in the corrosion resistance and biocompatibility of biomedical Ti-6Al-7Nb alloy using an electrochemical anodization treatment. Thin Solid Films 2013, 528, 157-162. [CrossRef] 
10. Catauro, M.; Bollino, F.; Papale, F.; Mozetic, P.; Rainer, A.; Trombetta, M. Biological response of human mesenchymal stromal cells to titanium grade 4 implants coated with $\mathrm{PCL} / \mathrm{ZrO}_{2}$ hybrid materials synthesized by sol-gel route: In vitro evaluation. Mater. Sci. Eng. C 2014, 45, 395-401. [CrossRef] [PubMed]

11. Kang, D.-S.; Lee, K.-J.; Kwon, E.-P.; Tsuchiyama, T.; Takaki, S. Variation of work hardening rate by oxygen contents in pure titanium alloy. Mater. Sci. Eng. A 2015, 632, 120-126. [CrossRef]

12. Wang, X.; Chen, Y.; Xu, L.; Liu, Z.; Woo, K.-D. Effects of Sn content on the microstructure, mechanical properties and biocompatibility of $\mathrm{Ti}-\mathrm{Nb}-\mathrm{Sn} /$ hydroxyapatite biocomposites synthesized by powder metallurgy. Mater. Des. 2013, 49, 511-519. [CrossRef]

13. Mareci, D.; Chelariu, R.; Gordin, D.-M.; Ungureanu, G.; Gloriant, T. Comparative corrosion study of Ti-Ta alloys for dental applications. Acta Biomater. 2009, 5, 3625-3639. [CrossRef] [PubMed]

14. Taddei, E.B.; Henriques, V.A.R.; Silva, C.R.M.; Cairo, C.A.A. Production of new titanium alloy for orthopedic implants. Mater. Sci. Eng. C 2004, 24, 683-687. [CrossRef]

15. Yu, S.; Yu, Z.; Wang, G.; Han, J.; Ma, X.; Dargusch, M.S. Biocompatibility and osteoconduction of active porous calcium-phosphate films on a novel Ti-3Zr-2Sn-3Mo-25Nb biomedical alloy. Colloids Surf. B Biointerfaces 2011, 85, 103-115. [CrossRef] [PubMed]

16. Tavares, A.M.G.; Ramos, W.S.; de Blas, J.C.G.; Lopes, E.S.N.; Caram, R.; Batista, W.W.; Souza, S.A. Influence of $\mathrm{Si}$ addition on the microstructure and mechanical properties of $\mathrm{Ti}-35 \mathrm{Nb}$ alloy for applications in orthopedic implants. J. Mech. Behav. Biomed. Mater. 2015, 51, 74-87. [CrossRef] [PubMed]

17. Niinomi, M. Mechanical properties of biomedical titanium alloys. Mater. Sci. Eng. A 1998, 243, $231-236$. [CrossRef]

18. Tobe, H.; Kim, H.Y.; Inamura, T.; Hosoda, H.; Nam, T.H.; Miyazaki, S. Effect of Nb content on deformation behavior and shape memory properties of Ti-Nb alloys. J. Alloys Compd. 2013, 577, S435-S438. [CrossRef]

19. Elias, L.M.; Schneider, S.G.; Schneider, S.; Silva, H.M.; Malvisi, F. Microstructural and mechanical characterization of biomedical Ti-Nb-Zr(-Ta) alloys. Mater. Sci. Eng. A 2006, 432, 108-112. [CrossRef]

20. Guo, S.; Zhang, J.; Cheng, X.; Zhao, X. A metastable $\beta$-type Ti-Nb binary alloy with low modulus and high strength. J. Alloys Compd. 2015, 644, 411-415. [CrossRef]

21. Song, Y.; Xu, D.S.; Yang, R.; Li, D.; Wu, W.T.; Guo, Z.X. Theoretical study of the effects of alloying elements on the strength and modulus of $\beta$-type bio-titanium alloys. Mater. Sci. Eng. A 1999, 260, 269-274. [CrossRef]

22. Zhang, W.-D.; Liu, Y.; Wu, H.; Song, M.; Zhang, T.-Y.; Lan, X.-D.; Yao, T.-H. Elastic modulus of phases in Ti-Mo alloys. Mater. Charact. 2015, 106, 302-307. [CrossRef]

23. Xie, F.; He, X.; Cao, S.; Mei, M.; Qu, X. Influence of pore characteristics on microstructure, mechanical properties and corrosion resistance of selective laser sintered porous Ti-Mo alloys for biomedical applications. Electrochim. Acta 2013, 105, 121-129. [CrossRef]

24. Liu, Y.; Li, K.; Wu, H.; Song, M.; Wang, W.; Li, N.; Tang, H. Synthesis of Ti-Ta alloys with dual structure by incomplete diffusion between elemental powders. J. Mech. Behav. Biomed. Mater. 2015, 51, 302-312. [CrossRef] [PubMed]

25. Kesteven, J.; Kannan, M.B.; Walter, R.; Khakbaz, H.; Choe, H.-C. Low elastic modulus Ti-Ta alloys for load-bearing permanent implants: Enhancing the biodegradation resistance by electrochemical surface engineering. Mater. Sci. Eng. C 2015, 46, 226-231. [CrossRef] [PubMed]

26. Farooq, M.U.; Khalid, F.A.; Zaigham, H.; Abidi, I.H. Superelastic behaviour of Ti-Nb-Al ternary shape memory alloys for biomedical applications. Mater. Lett. 2014, 121, 58-61. [CrossRef]

27. Kim, H.Y.; Ikehara, Y.; Kim, J.I.; Hosoda, H.; Miyazaki, S. Martensitic transformation, shape memory effect and superelasticity of Ti-Nb binary alloys. Acta Mater. 2006, 54, 2419-2429. [CrossRef]

28. Bociaga, D.; Komorowski, P.; Batory, D.; Szymanski, W.; Olejnik, A.; Jastrzebski, K.; Jakubowski, W. Silver-doped nanocomposite carbon coatings (Ag-DLC) for biomedical applications-Physiochemical and biological evaluation. Appl. Surf. Sci. 2015, 355, 388-397. [CrossRef]

29. Gimeno, M.; Pinczowski, P.; Pérez, M.; Giorello, A.; Martínez, M.Á.; Santamaría, J.; Arruebo, M.; Luján, L. A controlled antibiotic release system to prevent orthopedic-implant associated infections: An in vitro study. Eur. J. Pharm. Biopharm. 2015, 96, 264-271. [CrossRef] [PubMed]

30. Moreira, J.M.R.; Ponmozhi, J.; Campos, J.B.L.M.; Miranda, J.M.; Mergulhão, F.J. Micro- and macro-flow systems to study Escherichia coli adhesion to biomedical materials. Chem. Eng. Sci. 2015, 126, 440-445. [CrossRef] 
31. Fordham, W.R.; Redmond, S.; Westerland, A.; Cortes, E.G.; Walker, C.; Gallagher, C.; Medina, C.J.; Waecther, F.; Lunk, C.; Ostrum, R.F.; et al. Silver as a bactericidal coating for biomedical implants. Surf. Coat. Technol. 2014, 253, 52-57. [CrossRef]

32. Li, M.; Nan, L.; Xu, D.; Ren, G.; Yang, K. Antibacterial performance of a Cu-bearing stainless steel against microorganisms in tap water. J. Mater. Sci. Technol. 2015, 31, 243-251. [CrossRef]

33. Pang, L.Q.; Zhong, L.J.; Zhou, H.F.; Wu, X.E.; Chen, X.D. Grafting of ionic liquids on stainless steel surface for antibacterial application. Colloids Surf. B Biointerfaces 2015, 126, 162-168. [CrossRef] [PubMed]

34. Jin, X.; Gao, L.; Liu, E.; Yu, F.; Shu, X.; Wang, H. Microstructure, corrosion and tribological and antibacterial properties of Ti-Cu coated stainless steel. J. Mech. Behav. Biomed. Mater. 2015, 50, 23-32. [CrossRef] [PubMed]

35. Fojt, J.; Joska, L.; Malek, J.; Sefl, V. Corrosion behavior of Ti-39Nb alloy for dentistry. Mater. Sci. Eng. C 2015, 56, 532-537. [CrossRef] [PubMed]

36. Popa, A.C.; Stan, G.E.; Enculescu, M.; Tanase, C.; Tulyaganov, D.U.; Ferreira, J.M.F. Superior biofunctionality of dental implant fixtures uniformly coated with durable bioglass films by magnetron sputtering. J. Mech. Behav. Biomed. Mater. 2015, 51, 313-327. [CrossRef] [PubMed]

37. Wang, Y.; Yu, H.; Chen, C.; Zhao, Z. Review of the biocompatibility of micro-arc oxidation coated titanium alloys. Mater. Des. 2015, 85, 640-652. [CrossRef]

38. Fielding, G.A.; Roy, M.; Bandyopadhyay, A.; Bose, S. Antibacterial and biological characteristics of silver containing and strontium doped plasma sprayed hydroxyapatite coatings. Acta Biomater. 2012, 8, 3144-3152. [CrossRef] [PubMed]

39. Ma, Z.; Ren, L.; Liu, R.; Yang, K.; Zhang, Y.; Liao, Z.; Liu, W.; Qi, M.; Misra, R.D.K. Effect of heat treatment on $\mathrm{Cu}$ distribution, antibacterial performance and cytotoxicity of Ti-6Al-4V-5Cu alloy. J. Mater. Sci. Technol. 2015, 31, 723-732. [CrossRef]

40. Yang, S.-M.; Chen, Y.-C.; Chen, C.-H.; Huang, W.-P.; Lin, D.-Y. Microstructural characterization of $\delta / \gamma / \sigma / \gamma 2 / \chi$ phases in silver-doped 2205 duplex stainless steel under $800{ }^{\circ} \mathrm{C}$ aging. J. Alloys Compd. 2015, 633, 48-53. [CrossRef]

41. Lin, B.; Luo, Y.; Teng, Z.; Zhang, B.; Zhou, B.; Wang, Q. Development of silver/titanium dioxide/chitosan adipate nanocomposite as an antibacterial coating for fruit storage. LWT Food Sci. Technol. 2015, 63, 1206-1213. [CrossRef]

42. Feng, Q.-L.; Kim, T.-N.; Wu, J.; Park, E.-S.; Kim, J.-O.; Lim, D.-Y.; Cui, F.-Z. Antibacterial effects of Ag-HAp thin films on alumina substrates. Thin Solid Films 1998, 335, 214-219. [CrossRef]

43. Ou, S.-F.; Chung, R.-J.; Lin, L.-H.; Chiang, Y.-C.; Huang, C.-F.; Ou, K.-L. A mechanistic study on the antibacterial behavior of silver doped bioceramic. J. Alloys Compd. 2015, 629, 362-367. [CrossRef]

44. Matai, I.; Sachdev, A.; Dubey, P.; Uday Kumar, S.; Bhushan, B.; Gopinath, P. Antibacterial activity and mechanism of $\mathrm{Ag}-\mathrm{ZnO}$ nanocomposite on S. aureus and GFP-expressing antibiotic resistant E. coli. Colloids Surf. B Biointerfaces 2014, 115, 359-367. [CrossRef] [PubMed]

45. Koizhaiganova, M.; Yaşa, I.; Gülümser, G. Assessment of antibacterial activity of lining leather treated with silver doped hydroxyapatite. Int. Biodeterior. Biodegrad. 2015, 105, 262-267. [CrossRef]

46. Guzman, M.; Dille, J.; Godet, S. Synthesis and antibacterial activity of silver nanoparticles against gram-positive and gram-negative bacteria. Nanomed. Nanotechnol. Biol. Med. 2012, 8, 37-45. [CrossRef] [PubMed]

47. Sondi, I.; Salopek-Sondi, B. Silver nanoparticles as antimicrobial agent: A case study on E. coli as a model for Gram-negative bacteria. J. Colloid Interface Sci. 2004, 275, 177-182. [CrossRef] [PubMed]

48. Li, M.; Li, C.; Wang, F.; Zhang, W. Experimental study and thermodynamic assessment of the Ag-Ti system. Calphad 2005, 29, 269-275. [CrossRef]

49. Kang, M.-K.; Moon, S.-K.; Kwon, J.-S.; Kim, K.-M.; Kim, K.-N. Antibacterial effect of sand blasted, large-grit, acid-etched treated Ti-Ag alloys. Mater. Res. Bull. 2012, 47, 2952-2955. [CrossRef]

50. Chen, M.; Zhang, E.; Zhang, L. Microstructure, mechanical properties, bio-corrosion properties and antibacterial properties of Ti-Ag sintered alloys. Mater. Sci. Eng. C 2016, 62, 350-360. [CrossRef] [PubMed]

51. Chen, M.; Yang, L.; Zhang, L.; Han, Y.; Lu, Z.; Qin, G.; Zhang, E. Effect of nano/micro-Ag compound particles on the bio-corrosion, antibacterial properties and cell biocompatibility of Ti-Ag alloys. Mater. Sci. Eng. C 2017, 75, 906-917. [CrossRef] [PubMed] 
52. Somsanith, N.; Narayanan, T.S.N.S.; Kim, Y.-K.; Park, I.-S.; Bae, T.-S.; Lee, M.-H. Surface medication of Ti-15Mo alloy by thermal oxidation: Evaluation of surface characteristics and corrosion resistance in Ringer's solution. Appl. Surf. Sci. 2015, 356, 1117-1126. [CrossRef]

53. Zhao, Y.; Jiang, C.; Xu, Z.; Cai, F.; Zhang, Z.; Fu, P. Microstructure and corrosion behavior of Ti nanoparticles reinforced Ni-Ti composite coatings by electrodeposition. Mater. Des. 2015, 85, 39-46. [CrossRef]

54. Gad El-Rab, S.M.F.; Fadl-allah, S.A.; Montser, A.A. Improvement in antibacterial properties of Ti by electrodeposition of biomimetic Ca-P apatite coat on anodized titania. Appl. Surf. Sci. 2012, 261, 1-7. [CrossRef]

55. Niu, P.; Liu, B.; Li, Y.; Wang, Q.; Dong, A.; Hou, H.; Zhang, L.; Gao, Y.; Zhang, J. CdTe@SiO $2 / \mathrm{Ag}$ nanocomposites as antibacterial fluorescent markers for enhanced latent fingerprint detection. Dyes Pigments 2015, 119, 1-11. [CrossRef]

56. Ou, K.-L.; Weng, C.-C.; Lin, Y.-H.; Huang, M.-S. A promising of alloying modified beta-type Titanium-Niobium implant for biomedical applications: Microstructural characteristics, in vitro biocompatibility and antibacterial performance. J. Alloys Compd. 2017, 697, 231-238. [CrossRef]

57. Liao, K.-H.; Ou, K.-L.; Cheng, H.-C.; Lin, C.-T.; Peng, P.-W. Effect of silver on antibacterial properties of stainless steel. App. Surf. Sci. 2010, 256, 3642-3646. [CrossRef]

58. Liu, J.; Hu, M.; Song, Y.; Wang, F.; Ji, J.; Li, Z. A novel strategy to prepare silver nanoparticles by ethanol-induced shape conversion of silver dendrites from modified galvanic replacement. Synth. Met. 2014, 187, 185-192. [CrossRef]

59. Ashkarran, A.A.; Estakhri, S.; Nezhad, M.R.H.; Eshghi, S. Controlling the geometry of silver nanostructures for biological applications. Phys. Procedia 2013, 40, 76-83. [CrossRef]

60. Lu, W.; Yao, K.; Wang, J.; Yuan, J. Ionic liquids-water interfacial preparation of triangular Ag nanoplates and their shape-dependent antibacterial activity. J. Colloid Interface Sci. 2015, 437, 35-41. [CrossRef] [PubMed]

(C) 2017 by the authors. Licensee MDPI, Basel, Switzerland. This article is an open access article distributed under the terms and conditions of the Creative Commons Attribution (CC BY) license (http:/ / creativecommons.org/licenses/by/4.0/). 